\title{
Effects of High-Speed Rail on Sustainable Development of Urban Tourism: Evidence from Discrete Choice Model of Chinese Tourists' Preference for City Destinations
}

\author{
Weiwei Zhang * (1) and Lingling Jiang
}

check for updates

Citation: Zhang, W.; Jiang, L. Effects of High-Speed Rail on Sustainable Development of Urban Tourism: Evidence from Discrete Choice Model of Chinese Tourists' Preference for City Destinations. Sustainability 2021, 13, 10647. https://doi.org/10.3390/ su131910647

\section{Academic Editors: Marek}

Więckowski, Jan A. Wendt and Daniel Michniak

Received: 31 August 2021

Accepted: 21 September 2021

Published: 25 September 2021

Publisher's Note: MDPI stays neutral with regard to jurisdictional claims in published maps and institutional affiliations.

Copyright: (c) 2021 by the authors. Licensee MDPI, Basel, Switzerland. This article is an open access article distributed under the terms and conditions of the Creative Commons Attribution (CC BY) license (https:/ / creativecommons.org/licenses/by/ $4.0 /)$.
School of Business, Xiangtan University, Xiangtan 410005, China; 201921000234@smail.xtu.edu.cn

* Correspondence: wwzhang@xtu.edu.cn; Tel.: +86-15080765493
Abstract: In China, the opening of high-speed rails (HSR) brings significant changes to the sourcedestination spatial distance, the accessibility of destinations, and the spatial structure of tourist flows in each region, exerting varied HSR effects on different types of cities. Against this backdrop, it is meaningful to deeply explore tourists' preference for city destinations in the light of HSR effects. The exploration could contribute greatly to the planning, marketing, management, and sustainable development of urban tourism. This paper takes Xiangtan and Yueyang as typical cases of the diffusion effect and the corridor effect of HSR. Firstly, the factors affecting destination choice were identified, and the attribute levels were configured, forming multiple virtual alternatives. Next, questionnaire surveys were carried out to collect tourists' selections between each pair of alternatives. Further, a discrete choice model was constructed to assign a weight to each factor, reflecting its importance to tourists' decision-making regarding their destination selection and to disclose the law of tourists' preferences for destinations. The results showed that (1) Under the HSR diffusion effect, the top three factors affecting tourists' preference for destinations in Xiangtan are convenience, connection time, and popularity; under HSR corridor effect, the top three factors affecting the tourists' preference for destinations in Yueyang are reputation, convenience, and leisure and reception facilities (LRFs). (2) The destination preference is closely associated with personal features like gender, income, occupation, and fellow travelers. Tourists with different personal features give different attention to the various influencing factors. The research findings provide a reference for the sustainable development of urban tourism.

Keywords: high-speed rail (HSR) effects; preference for destinations; stated preference (SP) method; discrete choice model

\section{Introduction}

The general structure of this paper is as follows: Part 1 introduces the high-speed rail (HSR) effects on the sustainable development of urban tourism and summarizes the contents of this research, Part 2 expounds on the situation of the study area and explains the research methods, Part 3 compares the different preferences for destinations under different HSR effects, Part 4 points out the connections and differences between our results with the findings of predecessors, and Part 5 summarizes the laws of tourists' destination selection under HSR effect and provides suggestions on the sustainable development of urban tourism.

The sustainable development of urban tourism hinges on transportation infrastructure. In China, the expansion of the high-speed rail (HSR) network optimizes and upgrades tourism transportation and facilitates further high-quality development of urban tourism [1]. The fundamental reason is that the opening of the HSR brings significant changes to the accessibility [2-5] and spatial structure [6-9] of city destinations, the structure of source markets [10-12], and the spatiotemporal distribution of tourist flows [11,13]. 
The existing studies summarize the following effects of HSR on tourism flows: the Matthew effect, filtering effect, diffusion effect, superposition effect, and convergence effect. The Matthew effect means that tourist flows tend to cluster in destinations with superior geographical locations, tourist resource endowment, and tourist reception capability, as the opening of HSR compresses time and space and promotes the diffusion of tourist flows, allowing tourists to select between more destinations in the same period [14]. The filtering effect means that because of the time and space compression effect of HSR, some lesser-known tourism nodes with a low resource taste are easily edged out by well-known, far away destinations in the spatial competition of regional destinations, despite their advantages in location and travel distance. The diffusion effect refers to the spread of tourist flows from major tourism nodes to the attractive nodes in their surroundings after the opening of the HSR. Under the diffusion effect, the spatial form of tourist flows can be described by the typical core-periphery model. The superposition effect occurs between the tourism spaces of two source markets in a large region, as the opening of HSR greatly enlarges the radius of the $60 \%$ and $80 \%$ traveling spatial ranges [15]. The convergence effect means the tourist flows in two close cities both rise after the opening of the HSR [16].

From the perspective of tourists, HSR effects essentially characterize tourists' choice of destinations, as HSR minimizes the source destination time distance [8], improves the accessibility of destinations, and reshapes the tourism space of destinations. Previous studies have drawn an important conclusion: the opening of HSR reduces the traveling resistance over spatial distance and magnifies the impacts of the transportation network density, tourism resource endowment, and tourist reception capacity [17]. However, tourists' selection between destinations is influenced by multiple factors, namely, personal features [18-20], destination attributes [21-23] and travel features [24-26], and the need to be expounded from more diverse perspectives.

In the pre-HSR era, researchers noticed the important influence of personal features, e.g., income [27], age [28], and gender [29], and personal psychological features [18,30] over tourists' choice of destinations. For instance, Filimonau et al. [19] pointed out the decisive role of cultural background in tourists' selection between destinations. Sun et al. [31] considered sentiment orientation as an important cause of tourists' choice of destinations. During the selection between destinations, tourists also take account of destination features, e.g., climate [22], environmental conditions [23], and season [32], as well as the image of each destination [21]. For example, Rutty et al. [32] regarded climate as a key impactor of destination selection. Jalivand et al. [33] held that destination image significantly promotes travel intention. Onofri et al. [34] attributed the popularity of coastal areas among international tourists to their strong preference for culture and natural environments. Of course, travel features such as travel time [23], travel cost [26], and travel distance [35] also have a nonnegligible impact on tourists' decision-making of destination selection. Nicolau [24] demonstrated the influence of distance and price on the selection between destinations. Yu et al. [35] discovered that farmers prefer to select nearby destinations.

Therefore, it is meaningful to deeply explore tourists' preferences for destinations in the light of HSR effects [36]. Nevertheless, previous studies have mostly focused on how the opening of HSR changes the degree of influence of a single factor, failing to measure the action of multiple factors or capture the group differences in the preference for destinations under the effects of HSR. This paper attempts to make up for these gaps. The relevant results will contribute greatly to the planning, marketing, management, and sustainable development of urban tourism.

In this paper, the discrete choice model, a popular tool of economic management, was adopted to analyze the factors affecting tourists' selection between destinations. In tourism, the model has been mostly applied to the choice of destination [37-39], hotels [40,41], and host cities of conferences [42]. In terms of destination selection, the discrete choice model is often supported by theories of microeconomics, cognitive psychology, and marketing. Targeting local tourists of Hangzhou, Tang et al. [43] constructed a multi-index logit model with personal attributes as explanatory variables and destination as the explained vari- 
able and discovered a significant influence of age, gender, type of fellow travelers, and vacation length over the selection between destinations. From the angle of social economy, Chang et al. [44] examined the tourist preference for the attributes of theme parks, using choice experiments, the conditional logit model, and the random parameter logit model, and drew the following conclusions: consumers attach the greatest importance to amusement facilities, followed by thematic features [44]. In addition, a few scholars have introduced new models to study tourists' choice of destinations. From the perspective of tourist demand, Yao et al. [31] calculated the relative tourist preferences for 34 scenic spots in Dapeng Peninsula based on social media data and offered an innovative evaluation model for scenic spot planners and policymakers in the region.

The data of the discrete choice model mainly fall into two categories: revealed preference (RP) and stated preference (SP) [38]. Judging by the quantification method, RP is employed in most of the existing studies [45-47]; a survey is conducted on the actual and objective behaviors of the respondents in the real environment, and their preference is derived from the actual choices of real-world scenic spots. Despite high availability, $\mathrm{RP}$ data are strongly colinear. By contrast, the SP survey enables the respondents to fully consider the effects of multiple factors before selecting between virtual alternatives. In this way, the exact importance of all factors can be obtained objectively and sorted for comparison [48], which helps to find the preference law.

This paper applies the SP method to investigate tourists' preferences for destinations under HSR effects. Xiangtan and Yueyang were taken as the cases to study the diffusion effect and corridor effect of the HSR in Central China's Hunan Province. Through a literature review and expert interviews, the factors affecting destination choice were identified, and the attribute levels were configured as per the actual situation of the case cities, forming multiple virtual alternatives. Next, questionnaire surveys were carried out to collect tourists' selections between each pair of alternatives. Furthermore, a discrete choice model was constructed to assign a weight to each factor, reflecting its importance to tourists' decision-making of destination selection and to disclose the law of tourists' preferences for destinations. After that, model fitting was performed on the two case cities. The fitting results were compared to reveal the difference in importance between factors under different HSR effects. In addition, personal features were analyzed to identify the gap between groups in destination preference. On this basis, suggestions were put forward for tourism development in the two case cities. The research results provide a theoretical reference for the planning, marketing, and sustainable development of urban tourism under different HSR effects.

\section{Materials and Methods}

\subsection{Study Area}

This study chose Xiangtan and Yueyang, two cities in Central China's Hunan Province, as the cases. The two cities were selected for their obvious differences in tourist resources, transportation, recreational facilities, and HSR effects, as shown in Table 1. Through a comparative analysis of the two case cities, it is possible to reveal the disparity between influencing factors of tourists' selection between destinations under different HSR effects. It is also possible to select the influencing factors and configure the attribute levels required for the SP method such that virtual alternatives can be formed for tourists to choose from. The alternatives help to measure the degree of impact of each factor on tourists' selection between destinations. The ensuing analysis results regarding tourists' preference for destinations apply to the two case cities and provide a reference for tourism development in other cities. 
Table 1. Overview of the two case cities.

\begin{tabular}{|c|c|c|c|}
\hline & Xiangtan & Yueyang & Remarks \\
\hline Resources & $\begin{array}{c}\text { Xiangtan is a famous red tourism } \\
\text { city in China with a high density } \\
\text { of cultural and historical } \\
\text { resources. }\end{array}$ & $\begin{array}{l}\text { Yueyang is well-known for its } \\
\text { mountains, waters, ancient } \\
\text { buildings, historical } \\
\text { celebrities, and literature. } \\
\text { However, it is less popular } \\
\text { among tourists than the cities } \\
\text { along the Wuhan-Guangzhou } \\
\text { HSR, such as Changsha, } \\
\text { Wuhan, and Guangzhou. }\end{array}$ & \\
\hline Transportation & $\begin{array}{l}\text { Thanks to the Integrated } \\
\text { Development of Changsha, } \\
\text { Zhuzhou, and Xiangtan, Xiangtan } \\
\text { boasts comparable transportation } \\
\text { and location advantages to the } \\
\text { provincial capital Changsha, as } \\
\text { evidenced by its high accessibility. } \\
\text { Even Shaoshan, a county-level } \\
\text { city administered by Xiangtan } \\
\text { and hometown of Mao Zedong, } \\
\text { has an HSR station. }\end{array}$ & $\begin{array}{l}\text { The famous scenic spots are } \\
\text { far away from the downtown } \\
\text { and difficult to reach. }\end{array}$ & \\
\hline HSR effects & HSR diffusion effect & HSR corridor effect & $\begin{array}{l}\text { Algorithm: Holt's linear trend } \\
\text { method; } \\
\text { Data: pre-HSR number of tourists in } \\
\text { 2008 (Xiangtan: } 12.4435 \text { million; } \\
\text { Yueyang: } 13.7497 \text { million); post-HSR } \\
\text { number of tourists in } 2015 \text { (Xiangtan: } \\
\text { 37.87 million; Yueyang: } 43.05 \text { million); } \\
\text { Results: transportation-induced } \\
\text { variation in the number of tourists } \\
\text { (Xiangtan: } 2.5769 \text { million; Yueyang: } \\
-1.0051 \text { million) }\end{array}$ \\
\hline
\end{tabular}

\subsection{Selection of Influencing Factors}

There are extensive studies on the factors affecting tourists' selection between destinations. Jalivand considered the reputation of tourist cities a major impactor of the selection process and claimed that cities with a good reputation have a clear edge in competition [33]. Nostrand [49] believed that tourists value accessibility the most during the selection between destinations and that low accessibility would impede the incoming flow of tourists. Zhang Chunhui suggested that with the constant progress of society, leisure tourism facilities become an important influencing factor of destination selection, and the leisured atmosphere of a city greatly promotes tourist satisfaction [50].

Drawing on the literature, ten factors affecting tourists' selection between destinations were selected preliminarily: city attraction, tourist resource endowment, supporting facilities of scenic spots, economic development level, travel expense, accessibility, ecoenvironment, the brand image of the destination, local society and culture, and uniqueness of folk custom $[49,51-56]$. Considering the importance of the influencing factors and the purpose of our research, four of the ten preliminary factors were screened out, leaving six factors for further analysis. The removal of redundant factors helps to improve data quality because the quality of survey data depends on how easy it is for respondents to fill out the SP questionnaire. Since our research focused on transportation, a team of tourism experts from Hunan, China was organized to determine the relevant attributes and their levels according to empirical results of previous research and the actual situation of the case cities. Eventually, accessibility and city attraction were determined as the main factors affecting tourists' preference for destinations. The attributes of the two factors included 
entry time, connection time, convenience, popularity, reputation, and leisure and reception facilities (see Table 2).

Table 2. Attributes and their levels.

\begin{tabular}{|c|c|c|}
\hline Attribute & Description & Level \\
\hline Entry time & $\begin{array}{c}\text { Entry time is divided into two levels }(1 \mathrm{~h} \text { and } 3 \mathrm{~h}) \text { according to the actual time to travel to the } \\
\text { two case cities. }\end{array}$ & $\begin{array}{l}\text { (1) } 1 \mathrm{~h} ; \\
\text { (2) } 3 \mathrm{~h}\end{array}$ \\
\hline Connection time & $\begin{array}{l}\text { Connection time is divided into two levels ( } 15 \mathrm{~min} \text { and } 45 \mathrm{~min} \text { ) according to the time to travel } \\
\text { to the main scenic spots upon arrival at an HSR station in the case cities. }\end{array}$ & $\begin{array}{l}\text { (1) } 15 \mathrm{~min} ; \\
\text { (2) } 45 \mathrm{~min}\end{array}$ \\
\hline Convenience & $\begin{array}{l}\text { Convenience reflects the superiority of the traffic network between the source and the } \\
\text { destination. In this paper, convenience is rated by the number and frequency of other HSR } \\
\text { stations in Hunan Province, which are directly linked to the HSR stations in the case cities } \\
\text { and then normalized, with } 10 \text { points as the full mark. In this way, convenience is divided into } \\
\text { two levels: } 7 \text { and } 9 .\end{array}$ & (1) 7 ; (2) 9 \\
\hline Popularity & $\begin{array}{l}\text { Popularity refers to the extent of the case cities being known and recognized by the outside } \\
\text { world. In this paper, popularity is rated by the numbers of } 3 \mathrm{~A}, 4 \mathrm{~A} \text {, and } 5 \mathrm{~A} \text { scenic spots in the } \\
\text { city. One point is assigned to each } 3 \mathrm{~A} \text { scenic spot, two to each } 4 \mathrm{~A} \text { scenic spot, and three to } \\
\text { each 5A scenic spot. Then, the total score of a city is normalized, with } 10 \text { points as the full } \\
\text { mark. In this way, popularity is divided into two levels: } 6 \text { and } 10 \text {. }\end{array}$ & (1) 6 ; (2) 10 \\
\hline Reputation & $\begin{array}{l}\text { Reputation mirrors how much a city is trusted, liked, accepted, and welcomed by the public. } \\
\text { On the basis of more than } 200 \text { reviews on Ctrip.com and the number of scenic spots with a } \\
\text { score of }>4.0 \text {, this paper rates the reputation of each city and normalizes the score, with } 10 \\
\text { points as the full mark. In this way, reputation is divided into } 2 \text { levels: } 4 \text { and } 8 \text {. }\end{array}$ & (1) 4 ; (2) 8 \\
\hline $\begin{array}{l}\text { Leisure and } \\
\text { reception facilities } \\
\text { (LRFs) }\end{array}$ & $\begin{array}{l}\text { LRFs are measured by the number of all tourism and leisure facilities in the city, including } \\
\text { bed and breakfast (B\&B) tourism facilities, leisure agriculture facilities, and rural tourism } \\
\text { facilities, as well as recuperation and rehabilitation facilities. In this way, LRFs are divided } \\
\text { into two levels: rich and general. }\end{array}$ & $\begin{array}{l}\text { (1) rich; } \\
\text { (2) general }\end{array}$ \\
\hline
\end{tabular}

\subsubsection{Entry Time}

Time cost, an important part of travel cost [57], poses an obstacle to traveling [58]. Nostrand [49] suggested that destinations with a high traveling resistance, i.e., those with a long travel time and a high travel cost, are less attractive. Therefore, entry time is a key factor affecting the willingness to travel. Hence, this paper treated entry time as an attribute of the case cities.

\subsubsection{Connection Time}

It is important for destinations to provide convenient connecting traffic. Otherwise, tourists cannot easily reach the famous scenic spot across the city [59]. The opening of HSR significantly shortens the travel time outside the cities along the route and greatly compresses the space and time [60], making it much easier for people to travel from city to city. However, the cities along the HSR are often thronged by tourists. The ensuing traffic congestion pushes up the time cost of traveling within cities and from/to HSR stations and cancels out the fast speed of HSR over long distances [61]. Therefore, connection time is a major consideration of tourists during the selection between destination cities. Hence, this paper took connection time as an attribute of the case cities.

\subsubsection{Convenience}

Nolan et al. [62] pointed out that tourists want airliners to open more flights to satisfy their normal travel demand. Koo et al. [59] highlighted that the number of flights affects travel planning, pointing out that the variables of planning convenience (e.g., flight frequency) affect tourists' selection of destinations. As a means of rapid transportation, HSR carries similar features as airplanes. Hence, this paper chose convenience as another attribute of the case cities. 


\subsubsection{Popularity}

Hankinson (2005) [63] regarded popularity as one of the eight main clusters of attributes for the brand image of tourist cities. Y. et al. [64] considered the competitiveness of tourism resources as the main source of competitiveness of destination cities. Ahmed [65] pointed out the important influence of natural beauty on tourists' selection between destinations. Therefore, the popularity among tourists could greatly impact how tourists choose destinations. Hence, this paper adopted popularity as an attribute of the case cities.

\subsubsection{Reputation}

Xue Yongji et al. [66] discovered the significant positive effects of brand reputation on the perceived quality and brand trust of tourists and stated that brand reputation can indirectly enhance tourists' brand loyalty by promoting brand trust. Xu Chunxiao et al. [67] noticed the significant influence of scenic area reputation on the willingness to choose destinations. Through a thorough review of the previous literature, Herington et al. (2013) [68] summarized six components of destination attraction. One of them is reputation, which consists of the overall image, attitudes toward tourists, and attitudes toward tourism. Therefore, reputation is another factor affecting tourists' selection between destinations. Hence, this paper adopted reputation as an attribute of the case cities.

\subsubsection{LRFs}

In recent years, the concept of leisure has been in vogue among urban residents [69]. LRFs became a new decisive factor in destination selection. As stated by Chang et al. [70], the Grand Shangri-La (GSL) region is a magnet for international tourists. Apart from highend tourist experiences, the region offers attractive leisure, vacation, and health facilities, which boost the development of tourism in the region. Therefore, LRFs have a bearing on the tourists' selection between destination cities. Hence, this paper recognized LRFs as an attribute of the case cities.

\subsection{Questionnaire Design}

Our questionnaire surveys targeted local tourists in famous scenic spots of Xiangtan and Yueyang. The surveys on the two cities were conducted and analyzed separately. As shown in Appendix A, the questionnaire encompasses two parts. The first part focuses on personal features, namely, gender, age, occupation, education level, monthly income, and fellow travelers. The second part presents the alternatives of the SP survey. The SP question was as follows: "If you travel to Hunan by HSR, which city do you prefer to go to, A or $\mathrm{B}$ ? If neither is preferred, please choose $\mathrm{C}^{\prime \prime}$. Cities $\mathrm{A}$ and $\mathrm{B}$ were alternative combinations derived through the orthogonal design of various factors on different levels using SPSS. Option C meant that the respondent was not satisfied with A or B. In theory, if C is selected, then $C$ has a greater utility than $A$ or $B$. An example of alternative combinations is shown in Table 3.

To make it easier for respondents to fill out the questionnaires, the Generate Orthogonal Design module of SPSS was adopted to select eight alternatives and generate the most representative alternative combinations. Through manual screening, thirteen alternative combinations were removed for their large utility difference. The remaining fifteen combinations were split between the two questionnaires, one with seven combinations and the other with eight.

Table 3. An example of alternative combination.

\begin{tabular}{ccccccc}
\hline & \multicolumn{5}{c}{ Attributes } \\
& Entry & $\begin{array}{c}\text { Connection } \\
\text { Time }\end{array}$ & Convenience Popularity & Reputation & LRF \\
\hline City A & $3 \mathrm{~h}$ & $15 \mathrm{~min}$ & 7 & 6 & 8 & Rich \\
City B & $3 \mathrm{~h}$ & $40 \mathrm{~min}$ & 9 & 10 & 4 & Rich \\
\hline
\end{tabular}


The questionnaires were distributed in famous scenic spots of Xiangtan and Yueyang in May 2021. The respondents, who were mainly tourists to the two cities, filled out the questionnaires face-to-face using cellphones and other electronic devices. After completing their tours, these tourists had a direct understanding of the resources and features of the scenic spots. Specifically, a small-sample pre-survey was carried out. Then, the questionnaires were adjusted according to the feedback. After that, four surveyors issued a total of 420 formal questionnaires over five days, and 386 (92\%) valid questionnaires were recovered.

\subsection{Model Selection and Analysis \\ 2.4.1. Binomial Logit Model}

The binomial logit model was selected as the discrete choice model, which aims to maximize utility. The principle of the model is that consumers favor the products with the maximum utility. During our survey, respondents were asked to select the most effective option according to eigenvariables such as accessibility and city attraction. With these factors as explanatory variables, the utility function can be established as:

$$
U_{j}=V_{j}+\varepsilon
$$

On this basis, the binomial logit model can be obtained as:

$$
V_{j}=\sum_{1}^{k} \alpha_{k} x_{k j}
$$

where $j$ is the city option; $V_{j}$ is the utility determinant of city $j ; x_{1}$ is the entry time of city $j ; x_{2}$ is the connection time of scenic spots in city $j ; x_{3}-x_{6}$ are the degree of convenience, popularity, reputation, and LRFs of city $j$, respectively; and $\alpha_{k}$ is the variable to be estimated.

The respondents chose between alternatives by weighing their utilities. If $U_{j}>U_{m}$ $(m \neq j)$, then the respondents would choose alternative $j$. The probability for selecting alternative $j$ can be calculated by:

$$
P_{j}=P\left(U_{j}>U_{m}\right)
$$

\subsubsection{Willingness to Pay (WTP)}

The binomial logit model above can compute the WTP for attributes at different levels. The specific process is as follows: dividing the marginal utility of attributes by that of price and identifying the negative value, i.e., marginal rate of substitution. The WTP can be calculated by:

$$
\mathrm{WTP}=-\frac{\frac{\partial V}{\partial X_{k}}}{\frac{\partial V}{\partial p}}=-\frac{\alpha_{k}}{\alpha_{p}}
$$

This paper mainly investigated the preference of HSR tourists for destination cities. The HSR price is positively correlated with the travel time of HSR. The correlation is roughly $1 \mathrm{~h}=¥ 110$ (\$17). Therefore, Formula (4) can be corrected as:

$$
\mathrm{WTP}=-\frac{\frac{\partial V}{\partial X_{k}}}{\frac{\partial V}{\partial e t}} \cdot 17=-\frac{\alpha_{k}}{\alpha_{e t}} \cdot 17
$$

\section{Results}

\subsection{Descriptive Statistics}

This paper aimed to disclose the varied impacts of different factors on tourists' selection between destinations under HSR effects. Therefore, questionnaire surveys were carried out separately for tourists in Xiangtan (HSR diffusion effect) and Yueyang (HSR corridor effect). The descriptive statistics of the survey data were as follows: 
The respondents in Yueyang consisted of 108 females and 84 males. The gender difference was very small. Most respondents (40\%) were aged between 18 and 30. Except for the age group of $<18$ years, the number of respondents decreased with increasing age. In terms of education level, bachelor's degree holders were the largest group among the respondents. The proportions of junior high school graduates and below, senior high school graduates, junior college graduates, bachelor's degree holders, and master's degree holders and above were $7 \%, 13 \%, 15 \%, 40 \%$, and 25\%, respectively. Most $(57.63 \%)$ of the respondents were students, followed by government and public institution employees (16.95\%), enterprise employees (11.86\%), freelancers $(8.47 \%)$, and the self-employed (3.39\%). Regarding monthly income, $40.7 \%$ of the respondents earned less than CNY 3000 per month, $19.72 \%$ earned CNY 3000-5000 per month, 21.13\% earned CNY 5000-8000 per month, and $18.45 \%$ earned over CNY 8000 per month. Friends and family members made up the greatest portion $(84.50 \%)$ of fellow travelers.

The respondents in Xiangtan were evenly distributed across the two genders (males vs. females: $44 \%$ vs. $56 \%$ ). Similar to those in Yueyang, the respondents in Xiangtan were primarily young adults aged 18-30 years (39.05\%). In terms of education level, bachelor's degree holders were the largest group among the respondents. Most $(53.52 \%)$ of the respondents were students, followed by enterprise employees (16.90\%), government and public institution employees $(9.86 \%)$, freelancers $(8.47 \%)$, and the self-employed (5.63\%). Regarding monthly income, $34.24 \%$ of the respondents earned less than CNY 3000 per month, and 21.92\% earned CNY 3000-5000, CNY 5000-8000, or over CNY 8000 per month. Friends and family members make up the greatest portion $(83.05 \%)$ of fellow travelers.

In general, the samples had a balanced structure, which was suitable for model data analysis.

\subsection{Analysis of Fitting Results}

Based on the SP survey data and the purposed binomial logit model, the two cities, Xiangtan, and Yueyang, were fitted on Stata. The weight of each attribute was characterized by a utility coefficient. The positive/negative utility of the attribute was described by a positive/negative number. The greater the absolute value of the number, the more influential the attribute. The results showed that the goodness of fit always surpassed 0.14 [71], and the overall significance of the models satisfied $p=0.000<0.001$. The strong significance testified a good fitting effect. In addition, all attributes were statistically significant, and their coefficient signs were as expected. The fitting results are recorded in Table 4.

Table 4. Fitting results of binary logit model on tourists' preference for destinations.

\begin{tabular}{ccccccc}
\hline Variable & \multicolumn{2}{c}{ Xiangtan } & & Yueyang \\
\hline & Coefficient Value & Z-Score & WTP (USD) & $\begin{array}{c}\text { Coefficient } \\
\text { Value }\end{array}$ & Z-Score & WTP (USD) \\
\hline Entry time & $0.999899^{* * *}$ & 5.90 & & $0.79948^{* * *}$ & 3.08 & 2.48 \\
\hline Connection time & $1.452903^{* * *}$ & 8.08 & 24.70 & $0.62929^{* *}$ & 13.38 \\
\hline Convenience & $1.585737^{* * *}$ & 7.00 & 26.96 & $0.844799^{* * *}$ & 3.58 & 3.06 \\
\hline Popularity & $1.388766^{* * *}$ & 6.44 & 23.61 & $0.695811^{* * *}$ & 17.96 \\
\hline Reputation & $0.447957^{* * *}$ & 3.03 & 7.62 & $2.056439^{* * *}$ & 6.29 & 43.72 \\
\hline LRF & $0.547698^{* * *}$ & 2.91 & 9.31 & $0.807158^{* * *}$ & 2.74 \\
\hline$p$ & 0.000 & & & 0.000 & 17.16 \\
\hline
\end{tabular}

Note $1:^{* * *}$ and ${ }^{* *}$ represent significance on the levels of 0.01 and 0.05 respectively; Note 2: USD, US dollars $(1 \mathrm{USD}=6.4677 \mathrm{CNY})$.

As shown in Table 4, under the HSR diffusion effect, the top three influencing factors of the tourists' preference for destinations in Xiangtan were convenience, connection time, 
and popularity; under the HSR corridor effect, the top three influencing factors of the tourists' preference for destinations in Yueyang were reputation, convenience, and LRFs.

For tourists in Xiangtan, the utility coefficient of convenience (1.585737) was greater than that of any other factor, suggesting that the respondents attached the greatest importance to convenience. Connection time and popularity were next to convenience in the importance ranking. Their utility coefficients were 1.452903 and 1.388766 , respectively. Entry time was the fourth most important factor. LRFs and reputation were the least important factors.

For tourists in Yueyang, the utility coefficient of reputation (2.056439) was greater than that of any other factor, that is, the respondents considered reputation the leading factor. The second most important factor was convenience, with a utility coefficient of 0.844799 . In the third and fourth spots of importance ranking were LRFs and entry time, whose utility coefficients were 0.807158 and 0.79948 , respectively. Connection time had the least impact on tourists in Yueyang.

Through calculation, the following WTPs of various attributes in Xiangtan were obtained: USD 24.70 for connection time, USD 26.96 for convenience, USD 23.61 for popularity, USD 7.62 for reputation, and USD 9.31 for LRFs; the following WTPs of various attributes in Yueyang were obtained: USD 13.38 for connection time, USD 17.96 for convenience, USD 14.80 for popularity, USD 43.72 for reputation, and USD 17.16 for LRFs.

\subsection{Group Comparison of Destination Preference and Heterogeneity Analysis of WTP}

Different groups of respondents had different demands for tourism. Considering the actual situation of the samples and the reliability of analysis results, the preference differences induced by the factors affecting destination selection and personal attributes were classified simply. Each attribute was divided into two classes. Then, gender, income, occupation, education level, and fellow travelers were modeled separately to analyze the relationship between personal attributes and destination preference (see Table 5). The results showed that the goodness of fit was always greater than 0.14 , and the overall significance of the models satisfied $\mathrm{P}=0.000<0.001$. The strong significance testified to a good fitting effect.

Table 5. Tourist groups' destination preferences fitted by binomial logit model.

\begin{tabular}{|c|c|c|c|c|c|c|c|c|}
\hline \multirow[t]{2}{*}{ Variable } & & & \multicolumn{3}{|c|}{ Xiangtan } & \multicolumn{3}{|c|}{ Yueyang } \\
\hline & & & $\begin{array}{l}\text { Coefficient } \\
\text { Value }\end{array}$ & Z-Score & $\begin{array}{l}\text { WTP } \\
\text { (USD) }\end{array}$ & $\begin{array}{l}\text { Coefficient } \\
\text { Value }\end{array}$ & Z-Score & $\begin{array}{l}\text { WTP } \\
\text { (USD) }\end{array}$ \\
\hline \multirow{10}{*}{ Entry time } & \multirow{2}{*}{ Gender } & Male & $0.630891^{* *}$ & 2.15 & & $1.059916^{* * *}$ & 2.89 & \\
\hline & & Female & $1.180526^{* * *}$ & 5.62 & & 0.532768 * & 1.41 & \\
\hline & \multirow{2}{*}{ Monthly income } & $\geq \mathrm{CNY} 5000$ & $0.69803 * *$ & 2.35 & & - & 1.24 & \\
\hline & & $<$ CNY 5000 & $1.169303^{* * *}$ & 5.55 & & $1.501384^{* * *}$ & 3.33 & \\
\hline & \multirow{2}{*}{ Occupation } & $\begin{array}{l}\text { Free time } \\
\text { workers }\end{array}$ & $0.992772 * * *$ & 4.87 & & 0.522079 * & 1.72 & \\
\hline & & $\begin{array}{l}\text { Fixed time } \\
\text { workers }\end{array}$ & $1.068985^{* * *}$ & 3.41 & & $1.404886^{* * *}$ & 2.57 & \\
\hline & \multirow{2}{*}{ Education level } & $\begin{array}{c}\text { Below } \\
\text { bachelor's }\end{array}$ & $0.667758 *$ & 1.78 & & $0.972164^{* * *}$ & 2.81 & \\
\hline & & $\begin{array}{c}\text { Bachelor's and } \\
\text { above }\end{array}$ & $1.07929 * * *$ & 5.67 & & $0.815376^{* * *}$ & 2.9 & \\
\hline & \multirow[b]{2}{*}{ Fellow travelers } & Traveling alone & $0.997686^{* * *}$ & 2.88 & & 0.883384 * & 1.53 & \\
\hline & & $\begin{array}{l}\text { Not traveling } \\
\text { alone }\end{array}$ & $1.005439^{* * *}$ & 5.15 & & $0.750743^{* * *}$ & 2.55 & \\
\hline
\end{tabular}


Table 5. Cont.

\begin{tabular}{|c|c|c|c|c|c|c|c|c|}
\hline \multirow[t]{2}{*}{ Variable } & & & \multicolumn{3}{|c|}{ Xiangtan } & \multicolumn{3}{|c|}{ Yueyang } \\
\hline & & & $\begin{array}{c}\text { Coefficient } \\
\text { Value }\end{array}$ & Z-Score & $\begin{array}{l}\text { WTP } \\
\text { (USD) }\end{array}$ & $\begin{array}{l}\text { Coefficient } \\
\text { Value }\end{array}$ & Z-Score & $\begin{array}{l}\text { WTP } \\
\text { (USD) }\end{array}$ \\
\hline \multirow{10}{*}{$\begin{array}{l}\text { Connection } \\
\text { time }\end{array}$} & \multirow{2}{*}{ Gender } & Male & $1.235802^{* * *}$ & 4.01 & 33.3 & $0.950092 * *$ & 2.46 & 15.24 \\
\hline & & Female & $1.551845^{* * *}$ & 6.95 & 22.35 & - & 1.07 & - \\
\hline & \multirow{2}{*}{ Monthly income } & $\geq \mathrm{CNY} 5000$ & $0.860546^{* * *}$ & 2.74 & 20.96 & - & 0.37 & - \\
\hline & & $<$ CNY 5000 & $1.74436^{* * *}$ & 7.8 & 25.36 & $1.676327^{* * *}$ & 3.39 & 18.98 \\
\hline & \multirow{2}{*}{ Occupation } & $\begin{array}{l}\text { Free time } \\
\text { workers }\end{array}$ & $1.668177^{* * *}$ & 7.73 & 28.56 & - & 1.22 & - \\
\hline & & $\begin{array}{l}\text { Fixed time } \\
\text { workers }\end{array}$ & $0.933914^{* * *}$ & 2.8 & 14.85 & $1.086028^{* *}$ & 2.14 & 13.14 \\
\hline & \multirow{2}{*}{ Education level } & $\begin{array}{c}\text { Below } \\
\text { bachelor's }\end{array}$ & $1.159763^{* * *}$ & 2.9 & 29.52 & $0.708113^{* *}$ & 2.12 & 12.38 \\
\hline & & $\begin{array}{c}\text { Bachelor's and } \\
\text { above }\end{array}$ & $1.520682^{* * *}$ & 7.54 & 23.95 & $0.580959 * *$ & 2.13 & 12.11 \\
\hline & \multirow[b]{2}{*}{ Fellow travelers } & Traveling alone & $1.01283^{* * *}$ & 2.79 & 17.26 & $1.698435^{* * *}$ & 2.73 & 32.68 \\
\hline & & $\begin{array}{l}\text { Not traveling } \\
\text { alone }\end{array}$ & $1.588456^{* * *}$ & 7.65 & 26.85 & - & 1.21 & - \\
\hline \multirow{10}{*}{ Convenience } & \multirow{2}{*}{ Gender } & Male & $1.591585^{* * *}$ & 4.14 & 42.88 & $0.897215^{* * *}$ & 2.62 & 14.39 \\
\hline & & Female & $1.577374^{* * *}$ & 5.57 & 22.71 & $0.775467^{* *}$ & 2.36 & 24.74 \\
\hline & \multirow{2}{*}{ Monthly income } & $\geq \mathrm{CNY} 5000$ & $1.373119^{* * *}$ & 3.49 & 33.44 & 0.526288 * & 1.8 & - \\
\hline & & $<$ CNY 5000 & $1.71777^{* * *}$ & 6.14 & 24.97 & $1.450679^{* * *}$ & 3.38 & 16.43 \\
\hline & \multirow{2}{*}{ Occupation } & $\begin{array}{l}\text { Free time } \\
\text { workers }\end{array}$ & $1.702643^{* * *}$ & 6.31 & 29.15 & $0.387713^{*}$ & 1.38 & 12.62 \\
\hline & & $\begin{array}{l}\text { Fixed time } \\
\text { workers }\end{array}$ & $1.30426^{* * *}$ & 3.02 & 20.74 & $1.860554^{* * *}$ & 3.88 & 22.51 \\
\hline & \multirow{2}{*}{ Education level } & $\begin{array}{c}\text { Below } \\
\text { bachelor's }\end{array}$ & $1.825965^{* * *}$ & 3.57 & 46.48 & $1.093923^{* * *}$ & 3.51 & 19.13 \\
\hline & & $\begin{array}{c}\text { Bachelor's and } \\
\text { above }\end{array}$ & $1.537263^{* * *}$ & 6.07 & 24.21 & $0.95082^{* * *}$ & 3.77 & 19.82 \\
\hline & \multirow[b]{2}{*}{ Fellow travelers } & Traveling alone & $1.418889^{* * *}$ & 3.04 & 24.18 & $1.484469^{* * *}$ & 2.93 & 28.57 \\
\hline & & $\begin{array}{l}\text { Not traveling } \\
\text { alone }\end{array}$ & $1.643138^{* * *}$ & 6.32 & 27.78 & $0.639344^{* * *}$ & 2.35 & 14.48 \\
\hline \multirow{10}{*}{ Popularity } & \multirow{2}{*}{ Gender } & Male & $1.998204^{* * *}$ & 5.49 & 53.84 & 0.512121 * & 1.57 & 8.21 \\
\hline & & Female & $1.055013^{* * *}$ & 3.87 & 15.19 & $0.910189^{* * *}$ & 2.77 & 29.04 \\
\hline & \multirow{2}{*}{ Monthly income } & $\geq \mathrm{CNY} 5000$ & $1.146994^{* * *}$ & 3.06 & 27.93 & $0.760209^{* * *}$ & 2.55 & - \\
\hline & & $<\mathrm{CNY} 5000$ & $1.517307^{* * *}$ & 5.7 & 22.06 & $0.676668^{* *}$ & 1.85 & 7.66 \\
\hline & \multirow{2}{*}{ Occupation } & $\begin{array}{l}\text { Free time } \\
\text { workers }\end{array}$ & $1.46016^{* * *}$ & 5.78 & 25 & $0.589649^{* *}$ & 2.2 & 19.2 \\
\hline & & $\begin{array}{l}\text { Fixed time } \\
\text { workers }\end{array}$ & $1.121871^{* * *}$ & 2.62 & 17.84 & $1.03809^{* *}$ & 2.31 & 12.56 \\
\hline & \multirow{2}{*}{ Education level } & $\begin{array}{c}\text { Below } \\
\text { bachelor's }\end{array}$ & $1.55706^{* * *}$ & 3.22 & 39.64 & $0.604253^{* *}$ & 2.03 & 10.57 \\
\hline & & $\begin{array}{c}\text { Bachelor's and } \\
\text { above }\end{array}$ & $1.346246^{* *}$ & 5.58 & 21.2 & $0.701292 * * *$ & 2.84 & 14.62 \\
\hline & \multirow[b]{2}{*}{ Fellow travelers } & Traveling alone & $1.149201^{* * *}$ & 2.59 & 19.58 & 0.755490 * & 1.44 & 14.54 \\
\hline & & $\begin{array}{l}\text { Not traveling } \\
\text { alone }\end{array}$ & $1.466997^{* * *}$ & 5.93 & 24.8 & $0.700623^{* * *}$ & 2.75 & 15.86 \\
\hline
\end{tabular}


Table 5. Cont.

\begin{tabular}{|c|c|c|c|c|c|c|c|c|}
\hline \multirow[t]{2}{*}{ Variable } & & & \multicolumn{3}{|c|}{ Xiangtan } & \multicolumn{3}{|c|}{ Yueyang } \\
\hline & & & $\begin{array}{l}\text { Coefficient } \\
\text { Value }\end{array}$ & Z-Score & $\begin{array}{l}\text { WTP } \\
\text { (USD) }\end{array}$ & $\begin{array}{l}\text { Coefficient } \\
\text { Value }\end{array}$ & Z-Score & $\begin{array}{l}\text { WTP } \\
\text { (USD) }\end{array}$ \\
\hline \multirow{10}{*}{ Reputation } & \multirow{2}{*}{ Gender } & Male & - & 0.44 & - & $1.762719^{* * *}$ & 3.72 & 28.27 \\
\hline & & Female & $0.597817^{* * *}$ & 3.31 & 8.61 & $2.337517^{* * *}$ & 5.09 & 74.58 \\
\hline & \multirow[t]{2}{*}{ Monthly income } & $\geq \operatorname{CNY} 5,000$ & $\begin{array}{c}0.7093884 \\
* * *\end{array}$ & 2.64 & 17.28 & $2.087053^{* * *}$ & 5.06 & - \\
\hline & & $<\mathrm{CNY} 5,000$ & $0.323631 *$ & 1.82 & 4.7 & $2.064139 * * *$ & 3.68 & 23.37 \\
\hline & \multirow{2}{*}{ Occupation } & $\begin{array}{l}\text { Free time } \\
\text { workers }\end{array}$ & $0.291622 *$ & 1.65 & 4.99 & $1.738715^{* * *}$ & 4.6 & 56.61 \\
\hline & & $\begin{array}{l}\text { Fixed time } \\
\text { workers }\end{array}$ & $0.816029^{* * *}$ & 2.95 & 12.98 & $2.772855^{* * *}$ & 4.03 & 33.55 \\
\hline & \multirow{2}{*}{ Education level } & $\begin{array}{c}\text { Below } \\
\text { bachelor's }\end{array}$ & - & 0.34 & - & $2.317437^{* * *}$ & 5.24 & 40.52 \\
\hline & & $\begin{array}{c}\text { Bachelor's and } \\
\text { above }\end{array}$ & $0.517131^{* * *}$ & 3.15 & 8.15 & $2.092793 * * *$ & 5.91 & 43.63 \\
\hline & \multirow{2}{*}{ Fellow travelers } & Traveling alone & $\underset{* *}{0.7025872}$ & 2.29 & 11.97 & $2.464203 * * *$ & 3.28 & 47.42 \\
\hline & & $\begin{array}{l}\text { Not traveling } \\
\text { alone }\end{array}$ & 0.375151 ** & 2.22 & 6.34 & $1.929063^{* * *}$ & 5.27 & 43.68 \\
\hline \multirow{10}{*}{ LRF } & \multirow{2}{*}{ Gender } & Male & $0.773180^{* *}$ & 2.44 & 20.83 & 0.978881 ** & 2.28 & 15.7 \\
\hline & & Female & $0.397742 *$ & 1.67 & 5.73 & $0.639711 *$ & 1.57 & 20.41 \\
\hline & \multirow{2}{*}{ Monthly income } & $\geq \mathrm{CNY} 5000$ & - & 0.29 & - & $0.474412 *$ & 1.3 & - \\
\hline & & $<$ CNY 5000 & $0.769413^{* * *}$ & 3.32 & 11.19 & 1.335593 *** & 2.61 & 15.12 \\
\hline & \multirow{2}{*}{ Occupation } & $\begin{array}{l}\text { Free time } \\
\text { workers }\end{array}$ & $0.740568^{* * *}$ & 3.35 & 12.68 & $0.640239 * *$ & 1.85 & 20.85 \\
\hline & & $\begin{array}{l}\text { Fixed time } \\
\text { workers }\end{array}$ & - & -0.01 & - & $1.073702 *$ & 1.77 & 12.99 \\
\hline & \multirow{2}{*}{ Education level } & $\begin{array}{c}\text { Below } \\
\text { bachelor's }\end{array}$ & - & 0.91 & - & $1.073592^{* * *}$ & 2.7 & 18.77 \\
\hline & & $\begin{array}{c}\text { Bachelor's and } \\
\text { above }\end{array}$ & $0.587637^{* * *}$ & 2.79 & 9.25 & $0.719335^{* *}$ & 2.27 & 15 \\
\hline & \multirow[b]{2}{*}{ Fellow travelers } & Traveling alone & - & 0.87 & - & - & 1.33 & - \\
\hline & & $\begin{array}{l}\text { Not traveling } \\
\text { alone }\end{array}$ & $0.612511^{* * *}$ & 2.84 & 10.36 & $0.750903^{* *}$ & 2.22 & 43.68 \\
\hline
\end{tabular}

Note $1: * * * * *$, and $*$ represent significance on the levels of $0.01,0.05$, and 0.1 , respectively; - indicates that the corresponding variable is insignificant; Note 2: USD, US dollars(1 USD = 6.4677 CNY).

\subsubsection{Gender and Destination Preference}

For tourists in Xiangtan, males paid great attention to popularity, convenience, and connection time, while females attached the greatest importance to convenience, connection time, and entry time. Overall, tourists in Xiangtan, regardless of whether they were males or females, were concerned about convenience and connection time. The gender difference was that females also emphasized entry time, while males stressed popularity.

For tourists in Yueyang, males paid great attention to reputation, entry time, and LRFs, while females attached the greatest importance to reputation, popularity, and convenience. Overall, tourists in Yueyang, whether male or female, are highly tuned to reputation. The gender difference was that males cared greatly about entry time and LRFs, while females focused on popularity and convenience. 


\subsubsection{Income and Destination Preference}

This paper divided monthly income into two levels: $\geq$ CNY 5000, and $<$ CNY 5000. For tourists in Xiangtan, the tourists with a monthly income of $\geq$ CNY 5000 and those with monthly incomes of $<\mathrm{CNU} 5000$ both highlighted connection time, convenience, and popularity. For tourists in Yueyang, the tourists with a monthly income of $<\mathrm{CNY} 5000$ paid great attention to reputation, popularity, and convenience, while those with monthly incomes of $\geq$ CNY 5000 attached the greatest importance to reputation, connection time, and entry time. Therefore, tourists in Yueyang all focused on reputation, regardless of their income level. The income difference mainly laid in that the tourists with a monthly income of $<$ CNY 5000 were concerned about popularity and convenience, apart from reputation, while those with a monthly income of $\geq \mathrm{CNY} 5000$ cared greatly about connection time and entry time.

\subsubsection{Occupation and Destination Preference}

This paper divided occupations into free time workers and fixed time workers. The former workers can arrange their working hours flexibly and face few time constraints on traveling. These workers do not necessarily travel during minor vacations. They have large amounts of other spare time at their disposal. On the contrary, the travel time of fixed time workers is severely restricted by work.

For tourists in Xiangtan, free time workers paid great attention to convenience, connection time, and popularity, while fixed time workers attached the greatest importance to convenience, popularity, and entry time. Regardless of their occupation, tourists always considered convenience and popularity first during the selection of destinations. The difference was that free time workers also cared greatly about connection time, apart from the two factors, while fixed time workers stressed entry time.

For tourists in Yueyang, free time workers paid great attention to reputation, LRFs, and popularity, while fixed time workers attached the greatest importance to reputation, convenience, and entry time. Regardless of their occupation, the tourists gave top priority to reputation during the selection of destinations. The difference was that free time workers also cared greatly about LRFs and popularity, while fixed time workers focused on convenience and entry time.

\subsubsection{Education Level and Destination Preference}

In terms of education level, this paper classified the respondents into bachelor's degrees and above and below bachelor's degrees. For tourists in Xiangtan, both classes paid great attention to convenience, reputation, and connection time.

For tourists in Yueyang, those in the class of less than a bachelor's highlighted reputation, convenience, and LRF, and those in the other class also attached importance to reputation and convenience. However, the latter class emphasized entry time instead of LRFs.

\subsubsection{Fellow Travelers and Destination Preference}

In terms of fellow travelers, this paper divided the respondents into traveling alone and not traveling alone. For tourists in Xiangtan, those traveling alone and those not traveling alone both emphasized convenience, popularity, and connection time. The only difference was that those traveling alone emphasized popularity over connection time, while those not traveling alone emphasized connection time over popularity.

For tourists in Yueyang, those traveling alone were most concerned about reputation, connection time, and convenience, while those not traveling alone cared greatly about reputation, LRFs, and entry time. Both types of tourists highly valued reputation. However, those traveling alone also focused on connection time and convenience, while those not traveling alone were sensitive to LRFs and entry time. 


\section{Discussion}

This study carried out SP surveys separately for tourists to famous scenic spots in Xiangtan and Yueyang and analyzed the collected data with a discrete choice model. Then, the authors measured the varied effects of multiple factors (i.e., entry time, connection time, convenience, popularity, reputation, and LRFs) on tourists' decision-making of destination selection.

The analysis of the discrete choice model showed that under the HSR diffusion effect, convenience had the greatest impact on the destination selection for tourists in Xiangtan, and the impact was significantly positive. Hence, tourists in Xiangtan treated convenience as the most important factor in destination selection. This is consistent with Nostrand's [49] finding that destinations with a low time cost are highly attractive to tourists. Chul-Jin Lee and Jeong-Jun Kim [51] and Y. et al. [52] echoed our finding that accessibility and convenience are the focal points of tourists in destination selection. Our model also revealed that in addition to convenience, tourists pay great attention to popularity and connection time; popularity greatly increased the selection of a destination, while the connection time greatly suppressed the selection of a destination. This means that the respondents preferred to travel to more popular cities, where the famous scenic spots are close to HSR stations. This result agrees well with many scholars. For example, Kim [53] and Sun Gengnian et al. [72] held that tourists paid more attention to the resource features of destinations. Xu Chunxiao [67] and Wu Baoqing [73] noticed a significant effect of popularity on the willingness to choose a destination. Kwak Chun and Shin Eun Kyung [54] mentioned that the destination attributes, such as accessibility of scenic spots, had an immense influence on behavioral intentions. Bian Xianhong et al. [74] suggested that tourists might abandon a destination because of defects in the transportation system (e.g., connection transportation). Wang Hua [75] demonstrated that reducing the connection time between HSR stations and destinations facilitated tourists' travel decisions.

Under the HSR corridor effect, reputation, convenience, and LRFs were the top impactors on the destination selection of tourists in Yueyang, while popularity did not exert much effect. Located along the Wuhan-Guangzhou HSR, Yueyang is covered by the one-hour tourism circles of three provinces (Hunan, Hubei, and Guangdong). The opening of Wuhan-Guangzhou HSR connected the Wuhan Urban Agglomeration, ChangshaZhuzhou-Xiangtan Urban Agglomeration, and Pearl River Delta Urban Agglomeration into an organic whole. People can travel between any two cities in these agglomerations within 1-2 h [76]. Yueyang is a popular destination with famous scenic spots, such as Yueyang Tower and Junshan Island. However, the city is overshadowed by famous destinations along the Wuhan-Guangzhou HSR, such as Changsha, Wuhan, Guangzhou, and Xiangtan. Popularity-sensitive tourists are diverted to these famous destinations. This is consistent with the results of Huang Ailian [77].

The group comparison of destination preference indicated that in the two case cities, female and male tourists focused on different factors during destination selection. This result is basically consistent with the finding of Wang Shan [78]. The difference is that Wang Shan mainly discussed such factors as location, natural scenery, ticket price, regional culture, and tourism infrastructure. Meanwhile, this paper focused on the various effects of HSR opening and thus examined factors such as entry time, connection time, convenience, popularity, reputation, and LRF. Moreover, our research revealed that tourists in different occupations emphasized different factors during destination selection. This finding is in line with the conclusion of Wang Zanzan et al. [79], who claimed that facility conditions, service, tourist attractions, and tourism image have clearly different effects on tourists with different occupations. Furthermore, our research discovered that tourists with or without fellow travelers focused. A similar conclusion was drawn by Zhao Xianhong et al. [80], but they only stated that the mode of fellow travelers affects destination selection, failing to systematically measure the degree of influence of the mode on the factors affecting destination selection. In addition, tourists in Yueyang who belonged to different income groups cared about different factors during destination selection. Bai Qianwen et al. [81] came to 
the same conclusions. Hu Beiming [82], Liu Lu [83], and Ma Guishun [84] also pointed out the heterogeneity of tourist groups: different groups preferred different destinations. This paper classified and compared tourists on the basis of personal features and analyzed the factors considered by different types of tourists in destination selection. The research findings lay the basis for precision marketing in light of the unique preference of each tourist group and the classified planning and construction of service facilities for different groups of tourists.

\section{Conclusions and Suggestions}

\subsection{Conclusions}

This paper disclosed the laws of tourists' selection between destinations under the HSR fusion effect and HSR corridor effect and analyzed the influence of the HSR on the sustainable development of urban tourism.

(1) The research results showed that HSR effects and destination selection are two sides of the same coin. The existing studies summarized several types of HSR effects from the angle of tourist flows and proved with the gravity model that the opening of HSR greatly weakens how much distance impedes traveling. In this paper, the tourists' preference for destinations was discussed comparatively under two HSR effects. The predecessors' view that HSR promotes tourism was verified through significance tests on the attributes of transportation; the ranking of attribute coefficients was found to vary with HSR effects, suggesting that tourists have different considerations during destination selection when traveling is a sure thing. These results not only enrich the theories on HSR effects but also shed new light on sustainable urban tourism under different HSR effects.

(2) In the context of HSR, the comparative advantage of urban tourism was an important impactor in tourists' destination selection. Comparing the fitting results on tourists' choices of the case cities under the HSR diffusion effect and HSR corridor effect, the topranking items were the comparative advantage of the case cities. This ought to be considered by policymakers for preparing sustainable development strategies for urban tourism.

(3) Convenience of transportation has an important influence over tourists' selection between destinations. Drawing on the literature and expert opinions, this paper divided the HSR effects on tourists' destination selection into three factors: entry time, connection time, and convenience. The relevant studies suggested that convenience could affect tourists' destination choices but only tackled issues such as travel cost and accessibility. By contrast, this paper fully considered multiple influencing factors and confirmed the significant effect of convenience on tourists' destination selection.

(4) Tourists' selection between destinations could be affected by personal features. For tourists to Yueyang, males attached great importance to reputation, entry time, and LRF, while females highlighted the importance of reputation. The analysis of the two case cities revealed that tourists to different cities differed in the law of destination selection. City-specific analysis contributes immensely to the planning, marketing, management, and sustainable development of urban tourism.

\subsection{Suggestions}

(1) Attach equal importance to transportation and tourism in the pursuit of the sustainable development of urban tourism.

Our results show that both transportation and destination attraction significantly promote tourists' selection of a city destination. Therefore, a city should promote both factors during tourism development. First, the city should open more transport lines to scenic spots and reduce the connection time for tourists, making it more convenient for them to reach the scenic spots. Second, more diverse vehicles should be provided to satisfy the needs of different tourist groups. Third, the destination attraction must not be enhanced. The city should improve its popularity and reputation among tourists from multiple aspects: tourism products, tourism services, tourist safety, and complaint 
handling. Fourth, the economic construction should be reinforced to provide tourists with richer LRFs.

(2) Urban tourism planning and construction should expand relative advantages, make up for weak links, and realize high-quality tourism development.

According to the fitting results of our discrete choice model and the actual situation of the two case cities, tourists were most concerned about the relative advantages of destination cities during the selection between destinations and cared little about the relative disadvantages. On the one hand, the tourists to Xiangtan focused on convenience, popularity, and connection time. Xiangtan has several relative advantages: the city's convenient transportation, its proximity to Changsha, and the tourism distribution center of Hunan Province. Xiangtan is also a famous red tourism destination. An HSR station is located in the well-known scenic spot Shaoshan. It only takes a short time to travel from the station to the scenic spot. On the other hand, the tourists to Xiangtan did not have a high requirement for LRFs. As the seventh-largest economy in Hunan Province, Xiangtan does not operate enough LRFs. This corresponds to the tourists' preferences. To develop tourism, Xiangtan should further expand its relative advantages to stabilize existing tourists and attract potential tourists, and it should also make up for its weak links to meet the diverse needs of tourists, thereby achieving high-quality tourism development.

(3) Marketize urban tourism precisely in the light of the preference of each tourist group.

Our research found that different tourist groups have different preferences for destinations. To attract all types of tourists, a city should prepare marketing strategies in the light of the preference of each tourist group, aiming to realize precision marketing. For tourists in Xiangtan, males were more concerned about popularity than females. To attract male tourists, the city should fully expose its tourism products via news outlets, search engines, and browser ads from the angles of marketing, publicity, and service and improve the promotion of its scenic spots on we-media.

\subsection{Research Limitations and Directions for Future Studies}

There are several limitations of this research. Firstly, only two cities, namely, Xiangtan and Yueyang, were selected as the case cities for the HSR diffusion effect and HSR corridor effect. Given the uniqueness of the two cities in location, transportation, and resources, our analysis might not fully reveal the laws of tourists' destination selection under HSR effects. Future research will try to verify and enrich the results with more diverse cases. Secondly, only six attributes, i.e., entry time, connection time, convenience, popularity, reputation, and LRF were discussed because of the limitation of the SP questionnaire. The attributes that might affect tourists' destination selection need to be explored more comprehensively. To this end, more attributes, e.g., crowding degree, should be considered, the attributes could be surveyed in two separate questionnaires, and the data could be fused into a mixed dataset for model fitting [85]. Finally, the other HSR effects, such as the siphoning effect, will be taken into account, in addition to the corridor effect and diffusion effect.

Author Contributions: This article was coauthored by W.Z. and L.J.; W.Z. was responsible for fund acquisition, conceptualization, methodology design, supervision, drafting, review, and editing; L.J. was responsible for investigation, data curation, formal analysis, and drafting. All authors have read and agreed to the published version of the manuscript.

Funding: This research was funded by Hunan Provincial Science and Technology Department, grant number 2018JJ3503.

Institutional Review Board Statement: Not applicable.

Informed Consent Statement: Not applicable.

Data Availability Statement: The data presented in this study are available on request from the corresponding author. The data are not publicly available for privacy and ethical reasons.

Acknowledgments: Our thanks go to all the experts for their careful review and valuable comments on the manuscript. 
Conflicts of Interest: The authors declare no conflict of interest.

\section{Appendix A. Questionnaire}

Part 1. Please choose the appropriate option and tick the checkbox.

1. Your permanent residence is: [fill in the blank]

2. Would you like to travel to the city by high-speed rail?

$\square$ (1) Yes $\square$ (2) No (please stop answering)

3. Gender: $\square$ (1) Male $\square$ (2) Female

4. Age: $\square$ (1) below $18 \square$ (2) 18-30 (including 18) $\square$ (3) 31-50 $\square$ (4) More than 50

5. Occupation: $\square$ (1) Students $\square$ (2) Farmers $\square$ (3) Self-employed

$\square$ (4) Institutions $\square$ (5) Freelance $\square$ (6) Enterprise staff $\square$ (7) Retirees

6. Education: $\square$ (1) Junior middle school and blow $\square$ (2) High school $\square$ (3) College $\square$ (4)

Bachelor's $\square$ (5) Master's degree and above

7. Income: $\square$ (1) Below CNY $3000 \square$ (2) CNY 3000-5000 (including 3000)

$\square$ (3) CNY 5001-8000 (including 8000) $\square$ (4) Above CNY 8000 (per month)

8. Fellow travelers: $\square$ (1) Alone $\square$ (2) Friends $\square$ (3) Classmates

$\square$ (4) Colleagues $\square$ (5) Family $\square$ (6) Tour groups

\section{References}

1. Wang, D.; Chen, T.; Li, L.; Zhang, Y. Enlightenment and research of tourism impact on High-speed Rail. Sci. Geogr. Sin. 2012, 32, 322-328.

2. Jou, R.; Chen, K. The Relationship between High Speed Rail and Tourism. Sustainability 2020, 12, 5103. [CrossRef]

3. Andersson, D.E.; Shyr, O.F.; Fu, J. Does high-speed rail accessibility influence residential property prices? Hedonic estimates from southern Taiwan. J. Transp. Geogr. 2010, 18, 166-174. [CrossRef]

4. Wang, D.; Qian, J.; Chen, T.; Zhao, M.; Zhang, Y. Influence of the High-speed rail on the spatial pattern of regional tourism-Taken Beijing-Shanghai High-speed rail of China as example. Asia Pac. J. Tour. Res. 2014, 19, 890-912. [CrossRef]

5. Jiao, J.; Wang, J.; Zhang, F.; Jin, F.; Liu, W. Roles of accessibility, connectivity and spatial interdependence in realizing the economic impact of high-speed rail: Evidence from China. Transport. Policy 2020, 91, 1-15. [CrossRef]

6. Wang, D.; Niu, Y.; Chen, T.; Lin, L.; Tang, C. Optimizing tourist spatial structure for large scale regional metropolitan circles under the Beijing-Shanghai high-speed rail. Resour. Sci. 2015, 37, 581-592.

7. Wang, D.; Wang, L.; Chen, T.; Lu, L.; Niu, Y.; Lew, A.A. HSR mechanisms and effects on the spatial structure of regional tourism in China. J. Geogr. Sci. 2016, 26, 1725-1753. [CrossRef]

8. Hiramatsu, T. Unequal regional impacts of high speed rail on the tourism industry: A simulation analysis of the effects of Kyushu Shinkansen. Transportation 2018, 45, 677-701. [CrossRef]

9. Li, J.; Qian, Y.; Zeng, J.; Yin, F.; Zhu, L.; Guang, X. Research on the influence of a High-speed railway on the spatial structure of the Western Urban Agglomeration based on fractal theory-Taking the Chengdu-Chongqing Urban Agglomeration as an example. Sustainability 2020, 12, 7550. [CrossRef]

10. Yang, C.; Sung, Y. Constructing a mixed-logit model with market positioning to analyze the effects of new mode introduction. $J$. Transp. Geogr. 2010, 18, 175-182. [CrossRef]

11. Pagliara, F.; Pietra, A.L.; Gomez, J.; Vassallo, J.M. High Speed Rail and the tourism market: Evidence from the Madrid case study. Transport. Policy 2014, 37, 187-194. [CrossRef]

12. Albalate, D.; Fageda, X. High speed rail and tourism: Empirical evidence from Spain. Transport. Res. A-Pol. 2016, 85, 174-185. [CrossRef]

13. Li, L.; Lu, L.; Xu, Y.; Sun, X. Influence of high-speed rail on tourist flow network in typical tourist cities: An empirical study based on the Hefei-Fuzhou high-speed rail in China. Asia Pac. J. Tour. Res. 2020, 25, 1215-1231. [CrossRef]

14. Wang, Y.; Wang, J.; Wu, X. The influence of Harbin-Dalian high speed railway in the spatial structure oftourist flow. Nat. Sci. J. Harbin Norm. Univ. 2016, 32, 74-78.

15. Wang, D.; Chen, T.; Lu, L.; Wang, L.; Lew, A.A. Mechanism and HSR effect of spatial structure of regional tourist flow: Case study of Beijing-Shanghai HSR in China. Acta Geogr. Sin. 2015, 70, 214-233.

16. Wang, D. The Influence of Beijing-Shanghai High-speed Railway on Tourist Flow and Time-space Distribution. Tour. Trib. 2014, $29,75-82$.

17. Wang, D.; Niu, Y.; Wang, L. Influence of high-speed rail on choices of tourist destination based on the gravity model: A case study of Beijing-Shanghai high-speed rail in China. Geogr. Res. 2015, 34, 1770-1780.

18. Um, S.; Crompton, J.L. Attitude determinants in tourism destination choice. Ann. Tourism. Res. 1990, 17, 432-448. [CrossRef]

19. Lee, G.; Tussyadiah, I.P. Exploring familiarity and destination choice in international tourism. Asia Pac. J. Tour. Res. 2012, 17, 133-145. [CrossRef]

20. Filimonau, V.; Perez, L. National culture and tourist destination choice in the UK and Venezuela: An exploratory and preliminary study. Tourism. Geogr. 2018, 21, 1-26. [CrossRef] 
21. Bolan, P.; Williams, L. The role of image in service promotion: Focusing on the influence of film on consumer choice within tourism. Int. J. Consum. Stud. 2010, 32, 382-390. [CrossRef]

22. Rosselló, J.; Santana-Gallego, M. Recent trends in international tourist climate preferences: A revised picture for climatic change scenarios. Clim. Chang. 2014, 124, 119-132. [CrossRef]

23. Dumitras, D.E.; Muresan, I.C.; Jitea, I.M.; Mihai, V.C.; Balazs, S.E. Assessing tourists' preferences for recreational trips in national and natural parks as a premise for long-term sustainable management plans. Sustainability 2017, 9, 1596. [CrossRef]

24. Nicolau, J.L.; Más, F.J. The influence of distance and prices on the choice of tourist destinations: The moderating role of motivations. Tour. Manag. 2006, 27, 982-996. [CrossRef]

25. Wu, L.; Zhang, J.; Fujiwara, A. Representing tourists' heterogeneous choices of destination and travel party with an integrated latent class and nested logit model. Tour. Manag. 2011, 32, 1407-1413. [CrossRef]

26. Masiero, L.; Nicolau, J.L. Tourism market segmentation based on price sensitivity: Finding similar price preferences on tourism activities. J. Travel. Res. 2012, 51, 426-435. [CrossRef]

27. Djeri, L.; Armenski, T.; Jovanovic, T.; Dragin, A. How income influences the choice of tourism destination? Acta Oecon. 2014, 64, 219-237. [CrossRef]

28. Gardiner, S.; Grace, D.A.; King, C. The generation effect the future of domestic tourism in Australia. J. Travel. Res. 2014, 53, 705-720. [CrossRef]

29. Ruiz-Pérez, M.; Seguí-Pons, J.M. Transport mode choice for residents in a tourist destination: The long road to sustainability (the case of Mallorca, Spain). Sustainability 2020, 12, 9480. [CrossRef]

30. Lepp, A.; Gibson, H. Sensation seeking and tourism: Tourist role, perception of risk and destination choice. Tour. Manag. 2008, 29, 740-750. [CrossRef]

31. Sun, Y.; Ma, H.; Chan, E. A model to measure tourist preference toward scenic spots based on social media data: A case of Dapeng in China. Sustainability 2017, 10, 43. [CrossRef]

32. Rutty, M.; Scott, D.; Matthews, L.; Burrowes, R.; Trotman, A.; Charles, A. An Inter-Comparison of the holiday climate index (HCI:Beach) and the tourism climate index (TCI) to explain Canadian tourism arrivals to the Caribbean. Atmosphere 2020, 11, 412. [CrossRef]

33. Jalilvand, M.R.; Samiei, N. The impact of electronic word of mouth on a tourism destination choice: Testing the theory of planned behavior (TPB). Internet Res. 2012, 22, 591-612. [CrossRef]

34. Onofri, L.; Nunes, P.A.L.D. Beach 'lovers' and 'greens': A worldwide empirical analysis of coastal tourism. Ecol. Econ. 2013, 88, 49-56. [CrossRef]

35. Yu, F.; Huang, Z.; Lu, L.; Yin, S. Characteristics and influence mechanism of rural households' tourism destination choice behavior in developed regions:A case study of South Jiangsu. Acta Geogr. Sin. 2016, 71, 2233-2249.

36. Wang, D. Thinking on the new topics of tourism geography research in high-speed rail network era. Geogr. Res. 2016, 35, 403-418.

37. Jeng, J.M.; Fesenmaier, D.R. A neural network approach to discrete choice modeling. J. Travel. Tour. Mark. 1996, 5, 119-144. [CrossRef]

38. Albaladejo-Pina, I.P.; Díaz-Delfa, M.T. Tourist preferences for rural house stays: Evidence from discrete choice modelling in Spain. Tour. Manag. 2009, 30, 805-811. [CrossRef]

39. Orsi, F.; Geneletti, D. Assessing the effects of access policies on travel mode choices in an Alpine tourist destination. J. Transp. Geogr. 2014, 39, 21-35. [CrossRef]

40. Masiero, L.; Heo, C.Y.; Pan, B. Determining guests' willingness to pay for hotel room attributes with a discrete choice model. Int. J. Hosp. Manag. 2015, 49, 117-124. [CrossRef]

41. Masiero, L.; Nicolau, J.L. Choice behaviour in online hotel booking. Tourism. Econ. 2016, 22, 671-678. [CrossRef]

42. Crouch, G.I.; Chiappa, G.D.; Perdue, R.R. International convention tourism: A choice modelling experiment of host city competition. Tour. Manag. 2019, 71, 530-542. [CrossRef]

43. Tang, X.; Wang, D.; Sun, Y.; Chen, M.; Waygood, E.O.D. Choice behavior of tourism destination and travel mode: A case study of local residents in Hangzhou, China. J. Transp. Geogr. 2020, 89, 102895. [CrossRef]

44. Chang, M.Y.; Hsu, Y.S.; Chen, H.S. Choice experiment method for sustainable tourism in Theme Parks. Sustainability 2021, 13, 7146. [CrossRef]

45. Wu, L.; Zhang, J.; Fujiwara, A. Tourism participation and expenditure behaviour: Analysis using a scobit based discretecontinuous choice model. Ann. Tourism. Res. 2013, 40,1-17. [CrossRef]

46. Pan, X.; Rasouli, S.; Timmermans, H. Investigating tourist destination choice: Effect of destination image from social network members. Tour. Manag. 2021, 83, 104217. [CrossRef]

47. Kemal, Ç.A.; Tayfun, Y.; Zafer, A.; Siamak, K. The impact of narrow personality traits on entrepreneurial intention in developing countries: A comparison of Turkish and Iranian undergraduate students using ordered discrete choice models. Eur. Res. Manag. Bus. Econ. 2021, 27, 100138.

48. Mark, T.L.; Swait, J. Using stated preference and revealed preference modeling to evaluate prescribing decisions. Health Econ. 2004, 13, 563. [CrossRef]

49. Nostrand, C.V.; Sivaraman, V.; Pinjari, A.R. Analysis of long-distance vacation travel demand in the United States: A multiple discrete-continuous choice framework. Transportation 2013, 40, 151-171. [CrossRef] 
50. Zhang, C.; Ma, Y.; Bai, K. Asymmetric impact of destination attribute performance on tourists' overall satisfaction-A case study of Beijing. Bus. Manag. J. 2014, 36, 111-124.

51. Lee, C.-J.; Kim, J.-J. A Study on the impact of mannerism from tourism experience to destination choice attributes. J. Tour. Manag. Res. 2014, 18, 385-406.

52. Pan, Y.; Wang, X.; Ryan, C. Chinese seniors holidaying, elderly care, rural tourism and rural poverty alleviation programmes. J. Hosp. Tour. Manag. 2021, 46, 134-143. [CrossRef]

53. Kim, M.K. The effects of destination choice attributes on the perceived value of tourism resources in urban tourism. J. Mice Tour. Res. 2014, 14, 25-43.

54. Chun, K.; Kyung, E. The effect of Chinese tourists's destination choice attributes on behavioral intentions-Moderating effect of tourism constraints. J. Tour. Manag. Res. 2013, 17, 1-19.

55. Saeed, M.; Shafque, I. Customer-based brand equity and destination visit behaviour in the tourism industry: The contingent role of social media. Qual. Quant. Int. J. Methodol. 2020, 54, 1491-1512. [CrossRef]

56. Matthews, Y.; Scarpa, R.; Marsh, D. Cumulative attraction and spatial dependence in a destination choice model for beach recreation. Tour. Manag. 2018, 66, 318-328. [CrossRef]

57. Wang, T.; Tang, T.Q.; Chen, L.; Huang, H.J. Analysis of trip cost allowing late arrival in a traffic corridor with one entry and one exit under car-following model. Physica A 2019, 521, 387-398. [CrossRef]

58. Bigano, A.; Hamilton, J.M.; Tol, R.S.J. The impact of cmate on holiday destination choice. Clim. Chang. 2006, 76, 389-406. [CrossRef]

59. Koo, T.T.R.; Rashidi, T.H.; Park, J.W.; Wu, C.L.; Tseng, W.C. The effect of enhanced international air access on the demand for peripheral tourism destinations: Evidence from air itinerary choice behaviour of Korean visitors to Australia. Transport. Res. A-Pol. 2017, 106, 116-129. [CrossRef]

60. Wang, X.; Zou, T.Q. Impact of the high speed network on the development and distribution of chinese area's tourism industry. Econ. Geogr. 2010, 30, 1189-1194.

61. Niu, Y.; Wang, D. Characteristics and Modes of Connection System between Urban Transportation and High-speed Rail Station: Case Study of Suzhou and Shanghai. Tour. Trib. 2016, 31, 106-113.

62. Nolan, J.; Rowcroft, R.J. The Economics of Cost Recovery in Transport I I Small Market Air Service and Regional Policy. J. Transport. Econ. Policy 2005, 39, 363-378.

63. Hankinson, G. Destination brand images: A business tourism perspective. J. Serv. Mark. 2005, 19, 24-32. [CrossRef]

64. Shi, Y.; Zhong, L.; Chen, T.; Yu, H. Tourism competitiveness evaluation and spatio-temporal characteristics of Chinese border counties. Chin. Geogr. Sci. 2016, 26, 817-828. [CrossRef]

65. Ahmed, F.; Azam, M.S.; Bose, T.K. Factors affecting the selection of tour destination in bangladesh: An empirical analysis. Int. J. Bus. 2010, 5, 52-61.

66. Xue, Y.; Sun, Y. The relationship study on tourist brand recognition, perceived quality and brand loyalty of recreational tourisn with nature resources: Taking Beijing as examples. Resour. Sci. 2016, 38, 344-352.

67. Cao, W.; $\mathrm{Xu}, \mathrm{C}$. A research on the relationship between tourist destination trust and approaching intention: A case study of Shaoshan. J. Beijing Intl. Stud. Univ. 2014, 35, 178-185.

68. Herington, C.; Merrilees, B.; Wilkins, H. Preferences for destination attributes: Differences between short and long breaks. J. Vacat. Mark. 2013, 19, 149-163. [CrossRef]

69. Wu, Y. Viewing Guangzhou RBD from the perspective of leisure and Tourism. Tour. Trib. 2006, 21, 11.

70. Cheng, Q.; Zhong, F. Evaluation of tourism climate comfort in the Grand Shangri-La region. J. Mt. Sci.-Engl. 2019, 16, 1452-1469. [CrossRef]

71. Hensher, D.A.; Johnson, L.W. Applied discrete-choice modelling. Gen. Inf. 1981, 6, 774.

72. Sun, G.; Zhang, Y.; Xue, J. Scenery attraction, location accessibility and trade connection: Three factors and their influences on destination choice of Japanese tourists. Geogr. Res.-Aust. 2011, 30, 1032-1043.

73. Wu, B.; Wu, J.; Shi, X.; Zhang, T. How many people will visit a destination after hearing about it? The relationship between visiting rate and destination awareness. Tour. Trib. 2020, 35, 78-94.

74. Bian, X.; Wang, S. On the role of tourist transportation system in destination development. J. Anhui Univ. 2003, 27, 132-138.

75. Wang, H. Study on high-speed rail travel behavior of urban residents-A case study of five cities in Guangxi. Soc. Sci. 2016, 15-20. [CrossRef]

76. Liang, X. Discussion on the development opportunity of tourism industry in hunan province based on the dual locational space-The opening visual threshold of "wuguang high speed railway". Econ. Geogr. 2010, 30, 859-864.

77. Huang, A. Effects of High-speed railway on regional tourism development: Case of High-speed railway between Wuhan and Guangzhou. East China Econ. Manag. 2011, 25, 47-49.

78. Wang, S.; Wang, H. Tourist characteristics and preference and the response of regional tourism development: Take the Xinghu Scenic Spot in Zhaoqing, Guangdong Province as an example. Areal Res. Dev. 2021, 40, 97-102.

79. Wang, Z.; Feng, W.; Zhang, J.; Zhao, P.; Ren, R. Factors influencing the destination selection of tourists visiting the Wutai Mountain scenic. J. Arid Land Resour. Environ. 2018, 32, 198-202. [CrossRef]

80. Zhao, X. An Empirical Study of Dispersed Choice in Tourism Destinations Based on Tourist Specific Properties-A Case Study of Transit Inbound Tourists in Three Ports. Tour. Trib. 2009, 24, 60-65. 
81. Bai, Q.; Wu, J.; Luo, W.; Wu, B.; Shi, X.; Zhang, T. Discrepancy of tourism destination choice among the different income groups: A case study of Beijing, Wuhan and Xi'an. Hum. Geog. 2020, 35, 150-160.

82. Hu, B.; Huang, X. Research on the impact of high-speed rail development on post-modern tourism consumer behavior. J. Sichuan Norm. Univ. (Soc. Sci.) 2021, 48, 92-102.

83. Liu, L.; Zhang, J.; Wu, B.; Morrison, A.M. The Destination Choice Behavior of Chinese Backpackers: From a Perspective of Identity Theory. Tour. Trib. 2018, 33, 80-89.

84. Ma, G.; Long, J.; Li, H. A study on tourism destination choice influencing factors of different personality seniors. Geogr. Res.-Aust. 2012, 31, 2185-2196.

85. Roman, C.; Martin, J.C. Hotel attributes: Asymmetries in guest payments and gains-A stated preference approach. Tour. Manag. 2016, 52, 488-497. [CrossRef] 